\title{
Contemporary trends in sustainable development reporting of mineral resources companies
}

\author{
Vasiliy Murko ${ }^{1}$, Oksana Chernikova ${ }^{2 *}$, and Myrzatay Sultanaliev ${ }^{3}$ \\ ${ }^{1}$ T.F. Gorbachev Kuzbass State Technical University, Research Center for Mining and Deep Coal \\ Processing, 650000 Vesennaya Str., 28, Kemerovo, Russia \\ ${ }^{2}$ Siberian state industrial University, Department of Economics, Accounting and Finance, 654007, \\ Kirov Str., 42, Novokuznetsk, Russia \\ ${ }^{3}$ Research Institute of Energy and Economics, 720055, Akhunbayeva Str., 119, Bishkek, Kyrgyz \\ Republic
}

\begin{abstract}
The article analyzes contemporary trends in sustainable development reporting in Russian business practice, provides assessment of current situation with disclosure of non-financial information by national companies, including those of mineral resources sector, describes the main features of Russian socially-oriented reports, identifies insufficiencies of the reporting documentation provided. Relevance of the research is determined by active development of socially responsible investment with appreciation of ESG factors, increased attention of the investors to the long-term sustainability of companies, to the quality of financial and non-financial risks management. The focus on sustainable development is the key issue in shaping strategies of the global and Russian agenda. Consequently, requests from various stakeholder groups for information on companies activities in this regard are becoming more frequent. The purpose of the study is to analyze and assess trends in corporate sustainable development reporting in business practice of Russian companies, including mineral resource sector, and to develop recommendations for implementation of integrated document formats in accordance with international practice
\end{abstract}

\section{Introduction}

The current Russian economy can be characterized as extremely turbulent and prone to a systemic crisis. This economic background stimulates relapse of the most difficult management problem associated with development of reliable business reports addressed to the key stakeholders of the companies. One of the main features of the current situation is the intense activity of society and professional communities in the area of transparency requirements in relation to the form and content of corporate reporting. Socio-economic environment of the enterprise do not interpret corporate reporting only as a set of financial data, systematized in several traditional, generally accepted forms. Financial reporting has

\footnotetext{
${ }^{*}$ Corresponding author: chernikovaop@yandex.ru
} 
become one, but not the only element of data system called advanced corporate reporting, which must meet information needs of shareholders, government, investors, consumers, trade unions and various social groups. There is enough information to draw a conclusion that top managers of Russian enterprises have already realized the growing importance of non-financial indicators characterizing the impact of business in national economy and society. In this regard, research on trends in corporate non-financial reporting development in Russian practice is relevant. Systematization of data in three areas of companies' functioning is facilitated by reporting on sustainable development.

Approaches to sustainable development are based on compliance with the requirements of international standards and application of the best practices, effective risk management, maintaining a constant dialogue with stakeholders and resolving the most significant issues.

The issues of defining the role, process of generation and directly the content of corporate non-financial reporting are actively discussed in Russian and foreign scientific community. Some authors try to define the concept and role of non-financial reporting $[1,2]$, some consider it as a source of information about the company's activities, study its content $[3,4]$, the others analyze its impact on economic efficiency indicators $[5,6]$, the rest consider it as a mean of communication and image development $[7,8]$.

The results of the analysis of scientific research reliably prove the importance of social responsibility of business in Russian and world practice for preserving the ecological environment for the further development of society, improving the quality of life of people, and increasing the welfare of business. The studied experience in the development of nonfinancial reporting is not systematized; it presents scattered studies devoted to the analysis of various aspects of the problem under consideration. The results of the analysis of scientific research reliably prove the importance of social responsibility of business in Russian and world practice for preserving the ecological environment for the further development of society, improving the quality of life of people, and increasing the welfare of business. The studied experience in the development of non-financial reporting is not systematized; it presents scattered studies devoted to the analysis of various aspects of the problem under consideration.

\section{Methods}

The empirical base for this study was analysis of Russian and international experience in development of non-financial reporting. The system approach made it possible to study this issue comprehensively and holistically. Methodology of the study is resumed in scientific literature given in the list of references.

\section{Results and Discussion}

The Russian Union of Industrialists and Entrepreneurs currently maintains the national register of corporate non-financial reports. This is a databank of voluntary non-financial reports of organizations operating on the territory of the Russian Federation. The national register includes a register of companies that issue non-financial reports and a library of non-financial reports (electronic versions of officially published non-financial reports of the companies operating in Russia and some large multinational companies).

According to the owners and top managers decisions, non-financial corporate reports can be presented in one of the following options:

- social reports, which can be characterized as very variative in terms of information content from reports representing local situation in the field of human resources, charity or environment control activities to the complex reports, including economic, social and 
environmental aspects concurrently (in fact, such reports can be qualified as sustainability reports);

- environmental reports, which data describe environmental activities of a corporation;

- reports on sustainable development, reflecting the key economic, social and environmental results of a corporation;

- integrated reports that accumulate information reflecting impact of corporate strategy, management, results and prospects for added value generation in the short, medium and long term;

- industry reports that include information on social and labor relations in a particular industry. Such reports are provided by the All-Russian branch of the Association of Electric Power Industry Employers, the Zheldortrans Association, the Russian Union of Chemists, the Union of Russian Brewers and others.

As of May 2021, 197 companies entered the National Register, 1163 reports were registered, issued since 2000, including: environmental reports (ER) - 101, social reports (SR) - 374, reports on sustainable development (RSD) - 415, integrated reports - 273.

In the end of 2020 , leading positions are taken by the following industries: oil and gas (173 reports $-14.8 \%$ of the total number of reports), energy (287 reports $-24.7 \%$ ), metallurgy and mining (161 reports - 13.8\%), as well as finance and insurance (116 reports - 10\%). By a wide margin, they are followed by chemical, petrochemical and perfumery industries $(88$ reports $-7.6 \%$ ), food and other consumer goods manufacturing and telecommunications (59 reports - 5\%), non-profit organizations (39 reports - 3.4\%) ... In other sectors of the economy, there are just single reports so far.

Information that comprehensively reflects the companies activities is published in reports prepared according to the "triunique resume", including economic, social, environmental and management issues. There are overwhelming majority of such reports in the National Register, and their number is growing every year. At the same time, there are also adherents of thematic reports (environmental or social).

The results of analysis have shown that national companies attention to non-financial reporting depends on two key factors: level of international integration and residence status of their owners. In addition, it is necessary to note important role of foreign credit and investment processes in which an enterprise or its specific branch is involved - presence of foreign banks and investors associated with national companies by various economic relations obliges them to disclose their reports and be scrupulous in preparing relevant information.

Most often, information on the number and composition of personnel, labor protection and industrial safety (if relevant for the industry), charity is reflected in social and environmental sections, environmental indicators for the main impacts (emissions, waste, energy consumption) are included. Many companies report provide information on related policies and corporate programs.

At the same time, there is an evident difference in the quality of reporting information between annual reports of companies that have previously issued a separate non-financial report and those which do not have such experience: as a rule, past efforts to build a data collection system, for example, according to GRI, do not go unnoticed, and information is provided in more logical and evident way. At the same time, the opposite process is observed: companies that have previously issued a separate non-financial report, and then switched to an integrated one, begin to reduce information on social and especially environmental aspects, "returning" to the format of the report they have practiced 18 years ago.

Most of the annual reports still contain mainly financial and economic indicators, information on production activities and corporate governance, supplemented by a few (one or two indicators per report) data on environmental and social impacts. 
In addition, the study makes it possible to conclude that different standards in non-financial reports generation and the lack of developed mechanisms for responding to the behavior of key stakeholders leads to the following disadvantages:

- variety of content, formats, structure of the information provided complicates data analysis and comparison;

- lack of possibility to compare indicators presented in non-financial statements of various companies;

- incomparability of the reporting periods (one part of Russian companies uses reporting period equal to a year, the other - 2 years, the third - makes reports from time to time);

- prior presentation of information that enhance positive image, hiding information about the negative impact on the environment and social sphere;

- lack of regulated procedures for checking indicators of non-financial reporting.

Based on the results of such an analysis, there is an urgent need to develop a unified corporate reporting standard for non-financial indicators with an appendix reflecting industry specifics of the companies' activities, and to reform the system of audit procedures. Under these circumstances, the Ministry of Finance of the Russian Federation has identified the main direction in development of accounting and reporting, which leads to generation of a new format for corporate integrated reporting. This process is naturally based on the concept of "integrated thinking", which reflects an organization potential to create social value in the long term.

However, the idea of integrated reporting does not mean mechanically combining two reports (annual and non-financial) or expanding social and environmental data in an integrated report. The new report should present a completely new product that reveals the degree of integration of ideas of social responsibility into the internal systems of company management. There is an obvious need to establish visible relationship between the results of the company's core activities and its many consequences. This task can be seen as the main goal of integrated reporting.

The choice of an integrated reporting format was driven by the pursuit to comply with the best international experience in corporate reporting, as well as to strengthen the trust of stakeholders by providing complete information about their activities. Integrated reports provide clearer understanding of relationship between the financial and non-financial aspects of a company, which helps management make decisions more effectively, which, in turn, helps to reduce risks and increase investment attractiveness.

The global economic crisis has become a serious obstacle for metallurgical and mining companies and forced them to focus on the efficiency of operations and management.

The economic realities are such that raw material prices are highly volatile, so the strategy of all large metallurgical and mining companies should be based on increasing profitability through further growth in production efficiency. [9] At present, the situation in the global economy remains extremely unstable. In such conditions, the decline in global demand leads to a reduction in production of iron and steel, which greatly affects financial results of mining companies. In such a market situation, production and commercial costs of mining have exceeded acceptable levels. Strengthening requirements for implementation of international standards in the field of corporate governance and environmental protection are issues of concern to the largest companies.

The rate of open pit mining of coal in the Kemerovo Region is ahead of underground mining due to the higher costs of the latter. However, open pit mining causes significant damage to the environment, while companies are not interested in the costs of reclamation. Coal mines are often located near settlements, which cause great inconvenience for local citizens, since dust from the dumps is spread large areas around. Currently only $30 \%$ of coal in Kuzbass is mined underground, and $70 \%$ in open pit mines. The prevalence of open 
pit coal mining leads to an intensive worsening of environmental and social environment in the region.

In addition, one of the problems of using coal is generation of processing waste. The problem is especially acute in the coal regions of Russia, where a large amount of extracted minerals accumulates around mining and processing enterprises in form of the finely dispersed sludge in hydraulic dumps and sedimentation tanks, which requires introduction of the best available technologies into the practice of the consumer enterprises [10-12].

Though, only two Kuzbass companies in the mineral and raw materials sector of the economy are included in the National Register of corporate non-financial reports, these are SUEK JSC and Evraz JSC.

The level and rating of achieving the sustainable development goals of enterprises, including mining, can be determined using the "Responsibility and Transparency" and "Sustainable Development Vector" ESG stock indices which have been calculated by the Moscow Exchange since 2019.

The "Responsibility and Transparency" index reflects the general situation in disclosure of sustainable development information in public corporate reports of the largest Russian companies. Individual company index values are used to identify the best presentation practices. Based on these indicators, the rating of companies is compiled. Using this index, you can get information about transparency and quality of the company indicators disclosure to the stakeholders.

The "Sustainable Development Vector" index reflects dynamics of indicators of socioeconomic and environmental performance of companies. The index shows what dynamics of results does the disclosed data reflect, whether the ecological "price" of production is decreasing, whether more social benefits are offered.

There is a relationship between the two indices, since the results of the assessment within the framework of the "Responsibility and Openness" index determine the sample for calculating the "Sustainable Development Vector" index. At the same time, the main task of the indicators is not companies ranking, but general assessment of the situation and dynamics of its development, and the best practices identification.

For the survey, the sample was carried out among the largest Russian companies according to the RAEX 600 rating, based on the results of which 126 companies have been selected that prepare reports on sustainable development. In the course of the survey, 41 factors and 69 indicators were considered.

When calculating the indices, the areas of economic, social and environmental impact of the enterprise on the sustainable environment are taken into account. The analyzed indicators are aggregated according to 3 aspects. (Table 1). 
Table 1. Aspects and indicators taken into account when calculating indices.

\begin{tabular}{|l|l|}
\hline Aspects & \multicolumn{1}{|c|}{ Indicators } \\
\hline 1. Economic & $\begin{array}{l}\text { labor productivity; capital investments; taxes paid; product } \\
\text { quality; share of purchases from local suppliers; innovation } \\
\text { activity }\end{array}$ \\
\hline 2. Social & $\begin{array}{l}\text { number of staff; data on personnel performance; industrial } \\
\text { safety, labor protection; industrial safety management systems, } \\
\text { labor remuneration; spending on social programs for staff; } \\
\text { number of beneficiaries of social programs for staff; } \\
\text { management remuneration; staff turnover; training; personnel } \\
\text { training costs; labor relations; respect for human rights }\end{array}$ \\
\hline 3. Ecological & $\begin{array}{l}\text { air emissions; greenhouse gas emissions; energy efficiency and } \\
\text { energy consumption; water consumption; discharges to water } \\
\text { sources; waste management; environmental protection costs; } \\
\text { environmental management systems; accounting and assessment } \\
\text { of environmental risks of the financed projects; financing of } \\
\text { environmental projects and programs }\end{array}$ \\
\hline
\end{tabular}

The leaders of the Russian Union of Industrialists and Entrepreneurs indices in field of corporate stability, responsibility and openness for 2020 in mining and metallurgical industry were as follows: Evraz JSC, Nornickel PJSC, Petropavlovsk GC, Polymetal PJSC, Polyus PJSC, Severstal PJSC, SUEK JSC.

When studying reporting of the companies in mineral sector of the Kemerovo Region, it has been found that only two companies submit reports on sustainable development to the Russian Union of Industrialists and Entrepreneurs: SUEK JSC, Evraz JSC, which decompose sustainable development goals in three aspects necessary for stakeholders (Table 2). 
Table 2. Disclosure of the main goals of enterprises in 3 aspects of sustainable development.

\begin{tabular}{|c|c|c|c|}
\hline \multirow{2}{*}{ Company name } & \multicolumn{3}{|c|}{ Development goals of the company in terms of aspects } \\
\hline & Economic aspect & Social aspect & $\begin{array}{l}\text { Environmental } \\
\text { aspect }\end{array}$ \\
\hline $\begin{array}{c}\text { SUEK JSC } \\
{[13]}\end{array}$ & $\begin{array}{l}\text { - stable satisfaction of the } \\
\text { demand for affordable } \\
\text { and high-quality energy } \\
\text { resources; } \\
\text { - compliance of the } \\
\text { company's products with } \\
\text { the requirements of new } \\
\text { generation ecological } \\
\text { coal-fired power plants; } \\
\text { - development of } \\
\text { cogeneration capacities; } \\
\text { - increase in operating } \\
\text { efficiency }\end{array}$ & $\begin{array}{l}\text { - high level of industrial } \\
\text { safety, labor protection; } \\
\text { - professional } \\
\text { development and social } \\
\text { well-being of personnel; } \\
\text { - increasing efficiency } \\
\text { of the company's social } \\
\text { investments }\end{array}$ & $\begin{array}{l}\text { - reducing negative } \\
\text { impact on the } \\
\text { environment along } \\
\text { the entire cost } \\
\text { chain; } \\
\text { - biodiversity } \\
\text { conservation; } \\
\text { - rational use of } \\
\text { resources }\end{array}$ \\
\hline Evraz JSC [14] & $\begin{array}{l}\text { - economic stability } \\
\text { (maintain stable economic } \\
\text { growth and create long- } \\
\text { term value for the Group); } \\
\text { - creation of jobs in the } \\
\text { regions of presence; } \\
\text { - ensuring safe working } \\
\text { conditions }\end{array}$ & $\begin{array}{l}\text { - creation of a distance } \\
\text { learning system; } \\
\text { - creating a corporate } \\
\text { program aimed at } \\
\text { improving technical } \\
\text { skills and competencies } \\
\text { of the relevant } \\
\text { employees }\end{array}$ & $\begin{array}{l}\text { - modernization of } \\
\text { electrostatic } \\
\text { precipitators; } \\
\text { - increasing } \\
\text { efficiency of gas } \\
\text { cleaning plants; } \\
\text { - modernization of } \\
\text { the complex for the } \\
\text { final cooling of } \\
\text { reverse coke oven } \\
\text { gas }\end{array}$ \\
\hline
\end{tabular}

It should be noted that the completion and official registration of the new corporate integrated reporting format will make it possible to oblige the senior management of mining companies to report on the companies' payments to the state budget regularly (in the form of taxes, fines for environmental damage). The subsoil belongs to the state, that is, to the people.

Civil society organizations need to know what's going on in the industry by getting the information they need. Corporate integrated reporting is the source of this information. The owners of coal mining companies need to change dramatically the declarative nature of corporate social responsibility, especially in terms of the environmental component of corporate integrated reporting.

\section{Conclusion}

Introduction of an integrated sustainability reporting format into the practice of Russian companies will require management and authorities to implement the following measures recommended by the team of authors:

- reforming the system of official control bodies, in terms of increasing responsibility for the environmental situation of regional, local authorities and management of enterprises that violate environmental legislation; 
- development of system of internal control of information presented in non-financial reporting in order to increase trust of stakeholders and need to improve companies business processes;

- development of the check-list and methods for calculating economic, social and environmental indicators, taking into account the industry specifics of activities, mandatory for organizations to fill out;

- development of professional and educational standards and programs for training specialists involved in generation and audit of reports on sustainable development.

Folowing the principle of social responsibility will ensure sustainable business development for Russian companies in the long term, and reduce social, political and reputational risks.

\section{References}

1. A.R. Kulkarni Procedia Economics and Finance, 11, 33 (2014)

2. E.V. Arsenova, K. A. Nefedova, A. D. Neretina University Bulletin (State University of Management), 1, 178 (2014) (in Russian)

3. N. Evdokimova, D. Kotenok Scientific review, 5 (48), 6 (2018)

4. O.P. Chernikova, P.P. Baranov Gornyi Zhurnal, 3, 82 (2018)

5. S.S. Svechnikova Humanitarian Balkan Studies, 2 (8), 40 (2020)

6. E.A. Fedorova, D.O. Afanasyev, R.G. Nersesyan, S.V. Ledyaeva Journal of the New Economic Association, 2 (46), 73 (2020)

7. A.O. Afanasyeva, K.V. Apriyants Colloquium-journal, 17-9 (41) 45 (2019)

8. M.M. Basova Economic Sciences, 187111 (2020)

9. O.V. Glushakova, O.P. Chernikova, S.A. Strekalova Izvestiya Ferrous Metallurgy, 63(5), 379 (2020)

10. V.I. Murko, O.P. Chernikova, A.B. Yuriev, E.N. Temlyantseva IOP Conference Series: Earth and Environmental Science, 723(5) 052027 (2021)

11. A.E. Zakadyrin Mining information and analytical bulletin (scientific and technical journal), 6-1 55 (2020)

12. I.A. Korotkiy, E.N. Neverov, V.I. Murko, O.P. Chernikova Journal of Physics: Conference Series, 1749(1) 012044 (2021)

13. Official site of SUEK JSC [Electronic resource] Access mode: URL: http://www.suek.ru

14. Official site of Evraz JSC [Electronic resource] Access mode: URL: https://www.evraz.com/ru 